PRESCRIPTION FOR SURVIVAL 


\section{PRESCRIPTION FOR SURVIVAL}

Health and Safety in the Health Service

ALLAN KERR and

ROGER POOLE

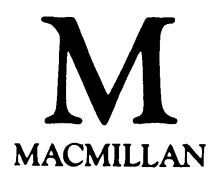


(C) Allan Kerr and Roger Poole 1984

All rights reserved. No part of this publication may be reproduced or transmitted, in any form or by any means, without permission

First published 1984 by

Higher and Further Education Division

MACMILLAN PUBLISHERS LTD

London and Basingstoke

Companies and representatives throughout the world

British Library Cataloguing in Publication Data

Kerr, Allan

Prescription for survival.

1. Medical care Great Britain Safety aspects

I. Title II. Poole, Roger

363.1'575 RA485

ISBN 978-0-333-35087-4 ISBN 978-1-349-17573-4 (eBook)

DOI 10.1007/978-1-349-17573-4 


\section{Contents}

Preface vii

Acknowledgements ix

How to Use This Book $\quad \mathrm{x}$

1 Why and How Accidents Occur 1

2 Where Accidents Happen 16

3 Ambulance Service and Community Staff 66

4 Maintenance Staff $\quad 77$

5 Hospital Environment 95

6 Stress and Backpain $\quad 125$

7 Sexual Harassment and Assaults 146

8 Preventing Accidents and Ill Health 163

9 The Future 194

Glossary 203

Bibliography 204

Index 207 


\section{Preface}

A glimpse of cynicism is likely to cross the face of any union safety rep told that health and safety is an issue taken seriously by health service employers. In fact, they could be forgiven for finding this hard to believe on the evidence before them. Just getting safety advice is a major exercise, as employers cannot or will not provide it. Even books on the subject of health and safety cater mainly for industry. For instance, they do not deal with the problems of lifting and handling of patients or the risks of contracting infectious diseases. Neither do they cater for the needs of community nurses and health visitors who work in the home, which is where most accidents happen.

In the pages which follow we cover most health and safety problems found in the health services. We hope the book will prove useful to all health service workers, particularly union safety reps. It builds on the TUC safety reps' course by providing an introduction to the problems unique to the health services and their control. We also hope that the book kindles a deeper interest in the subject and that some will want to delve deeper by making use of the references on which each chapter is based. Having said all that, administrators and others might read it simply to find out how trade unions view these matters. Of course, we hope they will then do something about them.

We have not catalogued health and safety problems by occupational groups since to do so is to misunderstand the nature of the health services. In hospitals, for instance, a team of people with various skills provide health care in the same workplace; doctors, nurses, porters and physiotherapists might find themselves facing the same health and safety problems while working together on a surgical ward. So we have provided information on the hazards in each workplace as well as on common problems like stress which affect all staff.

Of course, it is a paradox that a service dedicated to caring for the health of the community is at the same time putting the health of its own staff at risk. We hope this book will help, in some 
viii

\section{Preface}

measure, to redress this shortcoming by furnishing information which can be used by safety reps to make their workplaces safer.

Woolwich, London, 1983 A.K. R.P. 


\section{Acknowledgements}

We are indebted to the Executive Council of the National Union of Public Employees for their support and encouragement in the writing of this book. We are also grateful for having had the opportunity to draw upon the experiences of other trade unions in the Health Service.

Our thanks go to Mike Cunningham and Alan Dalton for reading the first draft and making many helpful comments that have made the final draft readable, though the final outcome, mistakes and all, is our responsibility. A special thanks must go to Pat Pumfrey for showing patience and good humour when typing and retyping the manuscript. 


\section{How to Use this Book}

Unless you have plenty of time on your hands you might not get round to reading all of this book. We don't expect you to, rather you can pick out the topics relevant to the problems you are dealing with at the time. For instance, before inspecting a ward, you should read the sections on wards, backpain, noise, stress and assaults. For anyone needing more detailed information we suggest using the references which form the basis of each chapter. Finally, at the end of each chapter a checklist is given; it is only a guide and should be tailored to meet local requirements. 